\title{
The Church of England, Homosexual Law Reform, and the Shaping of the Permissive Society,
} 1957-1979

\section{Laura Monica Ramsay}

\begin{abstract}
This article re-examines existing narratives of British permissiveness and secularization through a discussion of the Church of England's role in shaping the 1967 Sexual Offences Act and ongoing debates on homosexuality in the 1970s. It suggests - contrary to existing narratives of religious decline and marginalization-that the views of church commentators, and the opinions of the Established Church more generally, remained of real cultural and political influence in the years leading up to the 1967 Act. Religious authorities were thus more responsible for the moral landscape of the permissive society than historians previously assumed. Nevertheless, British permissiveness was full of contradictions, not only in terms of the unexpected ways in which reform was shaped and brought about, but in terms of the constraints of the new moral settlement which decriminalized homosexual behavior within modest boundaries. Such contradictions were not confined to the opinions of religious commentators-they were the genuine essence of the position on which the moral consensus in favor of homosexual law reform was based. Through a consideration of the final collapse of this moral consensus in the years after 1970, this article reassesses questions of the nature and timing of British secularization. It considers how the Church of England, although anticipating and shaping earlier developments in approaches toward sexual morality, unintentionally left itself out in the cold in the years after 1970, as progressive opinion began to move away from the consensus on which the 1967 Act had been based.
\end{abstract}

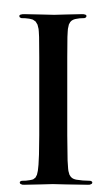

$\mathrm{n}$ recent years, attitudes toward sex and sexuality have been seen as a key indicator of religious decline in twentieth-century Britain. Just as youth culture, legislative reform, and attitudes toward sex outside of marriage have been seen as signifying the erosion of religious authority and Christian morality, liberal and radical Christian approaches toward sex issues have been used as a way of measuring postwar social progress and permissiveness. ${ }^{1}$ In many respects, this is a welcome development that allows for the re-evaluation of a tired and overgeneralized reading of postwar shifts in sexual behavior and culture, often supported by an earlier

Laura Monica Ramsay teaches in the Department of History at the University of Nottingham. She is most grateful to Harry Cocks and the editors and anonymous reviewers at Journal of British Studies for their thought-provoking comments on earlier drafts of this work. She also thanks Lambeth Palace Library and the Church of England Record Centre for kind permission to use their archives.

${ }^{1}$ See Callum G. Brown, "Religion, and the Single Woman c.1950-75: The Importance of a 'Short' Sexual Revolution to the English Religious Crisis of the Sixties," Twentieth Century British History 22, no. 2 (June 2011): 189-215; Hugh McLeod, The Religious Crisis of the 1960s (Oxford, 2007); Callum G. Brown, Religion and Society in Twentieth-Century Britain (Harlow, 2006). 
generation of historical scholarship that tended to view religious discourses as essentially backward looking, inflexible, and unwilling (or unable) to face new challenges and changes to traditional Christian morality. While skepticism of attempts to revise this view is understandable given the present context of ongoing religious disputes surrounding sexuality - the Anglican Church remains in turmoil over divisive matters of human sexuality, causing anguish, disappointment, and exasperation for a great many people - the role of Christianity in the making of modern sexuality needs to be historically reconsidered in a way that acknowledges the contradictions, tensions, and ambiguities of Christian positions. There remains some way to go toward rethinking our historiographical assumptions and understanding the complexities of the moral and sexual transformations of the period. ${ }^{2}$

This article re-examines existing narratives of permissiveness and secularization in 1960s and '70s Britain. First, it discusses the Church of England's role in framing the 1967 Sexual Offences Act that decriminalized private homosexual acts between two men over the age of twenty-one in England and Wales. ${ }^{3}$ The church played a vital role in influencing the shape and passage of this permissive legislation in the 1960s. Rather than a marginalized and declining authority on sexual issues, the Established Church retained real social and political significance in the parliamentary and wider public debate. Bishops in the House of Lords provided a leading voice in shaping the boundaries of the new Act and in legitimizing the moral position that underpinned parliamentary support for the controversial bill. In this way, it can be seen that Anglican voices were more responsible for the shifts in the moral landscape of the permissive society than hitherto assumed. The church helped to drive changes in sexual attitudes rather than simply being driven by them. Nevertheless, it is also acknowledged that there was a diversity of opinions on homosexuality within the church, which included significant elements of hostility toward legal reform. This plethora of voices limited the extent to which Anglican attitudes toward homosexuality were radically altered in this period, and resulted in considerable contradictions and tensions within the church's position of support for decriminalization.

Second, the article considers the church's relationship with homophile campaigning organizations such as the Homosexual Law Reform Society and Albany Trust. While there was a great deal of common ground and some cooperation between the church and these groups in the lead-up to the 1967 Act (indeed, homophile campaigning groups saw church support for homosexual law reform as vital to their success), tension and uneasiness characterized their working relationships. To some this may appear unsurprising, yet, until recently, religious institutions remained largely absent, or were brushed aside as inherently anti-permissive, within existing

\footnotetext{
${ }^{2}$ For recent calls to push the historiography in this direction, see Frank Mort, "The Ben Pimlott Memorial Lecture 2010: The Permissive Society Revisited," Twentieth Century British History 22, no. 2 (June 2011): 269-98; Matthew Grimley, "Law, Morality and Secularisation: The Church of England and the Wolfenden Report, 1954-1967," Journal of Ecclesiastical History 60, no. 4 (October 2009): 725-41.

${ }^{3}$ Due to this emphasis on criminalizing male homosexual activity, the following discussion focuses for the most part on the Church of England's engagement with male homosexuality. For discussion of Christian commentaries on female homoeroticism, see Sue Morgan, "Sex and Common-Sense: Maude Royden, Religion, and Modern Sexuality," Journal of British Studies 52, no. 1 (January 2013): 153-78, at 173-74; Sue Morgan, "The Word Made Flesh': Women, Religion and Sexual Cultures," in Women, Gender and Religious Cultures in Britain, 1800-1940, ed. Sue Morgan and Jacqueline deVries (London, 2010), 159-87, at 175-79.
} 
historical accounts. ${ }^{4}$ The point is not simply that this constructive relationship between the church and the homophile movement existed but rather it is significant in confirming the existence of an uneasy moral consensus on which homosexual law reform in England and Wales was based. By examining the extent of this consensus and its influence among legal reformers, social commentators, and campaigning organizations, we are able to address some of the broader contradictions of homosexual law reform and to question the nature of permissiveness in regard to this issue.

"Permissiveness" has long been recognized as a problematic, slippery, and incoherent concept, not least because its meaning and effect have evolved over time and incorporated contradictory tendencies. ${ }^{5}$ It is employed as a catch-all term to describe the increasing liberalization of behaviors and beliefs. In connection with issues of sexuality, it tends to signify new approaches toward morality, greater individualism, freedom, openness, and pleasure. ${ }^{6}$ If homosexual law reform represents the shifting moral landscape of postwar Britain, then the church's role in helping to create the conditions for that shift sheds further light on the inconsistencies of permissiveness. In relation to homosexuality, supporters of law reform shared a moral outlook that, rather than indicating support for greater individualism in sexual behavior, sought to reform the law while maintaining that homosexual behavior was immoral and not in any way to be accepted or encouraged. Homosexuality, from this perspective, presented a "problem" of social pathology that was best solved by decriminalizing homosexual acts. This moral consensus had been gaining ground among social commentators and campaigning organizations ever since the Departmental Committee on Homosexual Offences and Prostitution (better known as the Wolfenden committee) had put forward its controversial recommendations for law reform in the 1950s. ${ }^{7}$ In 1967, supporters of legal reform converged in confirming this moral outlook and in creating a particular idea of homosexual subjectivity-the discreet and respectable homosexual. ${ }^{8}$ Through the following case study, we see that, in shaping this conception of homosexuality as an ethical and subjective position and providing moral justification for reform, Christian commentators played an important role in creating

\footnotetext{
${ }^{4}$ For recent revisionism, see Jeff Meek, "Scottish Churches, Morality and Homosexual Law Reform, 1957-1980," Journal of Ecclesiastical History 66, no. 3 (July 2015): 596-613; Timothy Willem Jones, Sexual Politics in the Church of England, 1857-1957 (Oxford, 2013); Hugh McLeod, "Homosexual Law Reform, 1953-1967," in From the Reformation to the Permissive Society: A Miscellany in Celebration of the 400th Anniversary of Lambeth Palace Library, ed. Melanie Barber, Stephen Taylor, and Gabriel Sewell (Suffolk, 2010), 657-78; Graham Willett, "The Church of England and the Origins of Homosexual Law Reform," Journal of Religious History 33, no. 4 (December 2009): 418-34; Grimley, "Law, Morality and Secularisation."

5 Mort, "The Permissive Society Revisited"; Stuart Hall, "Reformism and the Legislation of Consent," in Permissiveness and Control: The Fate of the Sixties Legislation, ed. the National Deviancy Conference (London, 1979), 1-43.

${ }^{6}$ Marcus Collins, "Introduction: The Permissive Society and Its Enemies," in The Permissive Society and Its Enemies: Sixties British Culture, ed. Marcus Collins (London, 2007), 1-40.

7 The Wolfenden report recommended that private homosexual behavior between consenting adults aged 21 and over should no longer be a criminal offence. Home Office, Scottish Home Department, Report of the Committee on Homosexual Offences and Prostitution, Cmnd. 247 (London, 1957), 115-16.

${ }^{8}$ Frank Mort, Capital Affairs: London and the Making of the Permissive Society (New Haven, 2010), 355-56; Matt Houlbrook, Queer London: Perils and Pleasures in the Sexual Metropolis, 1918-1957 (London, 2005), 241-63.
} 
the binary opposition between homosexuality and heterosexuality that emerged in the postwar years.

Finally, the article considers the growing difficulties and divisions faced by the church in the years after 1967 as Anglicans tried to revise their position on homosexuality, especially attitudes toward homosexual relationships. In the lead-up to the Sexual Offences Act, Anglican commentators had operated within the framework of the shared moral consensus and cultivated an important role for themselves in legitimizing that position from a moral and religious standpoint. In the 1970s, however, a new mood in sexual politics and social action took hold and pushed back against the moral consensus on which homosexual law reform had been based. While some Anglicans encouraged the church to respond by re-evaluating its approach toward homosexuality, others remained firmly wedded to older ideas and solutions. Despite having anticipated earlier social and cultural developments relating to issues of homosexuality, the church reached an impasse after 1967 in disputes between its reforming and conservative elements. Consequently, it began to lose pace with progressive opinion and came under increasing criticism from within and without. This development further reveals the processes of religious decline in postwar Britain. In the late 1960s, the church demonstrated its ongoing social and political significance in the parliamentary and wider public debate on homosexuality. Yet, once the moral consensus began to crumble, the church was left in the 1970s without the ideological supports on which it had claimed to intervene in national debates on issues of sexuality. Increasingly, it was left out in the cold.

\section{EPISCOPAL SUPPORT FOR HOMOSEXUAL LAW REFORM}

Between 1965 and 1967, Anglican bishops in the House of Lords played a leading role in shaping the sexual offences bill and securing its passage into law. Yet it is important to emphasize that the bishops' seemingly unanimous support for decriminalization was something of an illusion. While the episcopal position was mistakenly perceived as reflecting the wider support of the British churches for homosexual law reform, in reality, only around three-fifths of the Lords Spiritual took part in the debates and voting on the bill. In large part, the consensus was a constructed one, led by Michael Ramsey, the archbishop of Canterbury, with considerable encouragement from Arthur Gore, eighth earl of Arran, the leading advocate of homosexual law reform in the House of Lords. ${ }^{9}$ On a practical level, support was orchestrated by Robert Beloe, Ramsey's lay secretary, who ensured that episcopal representatives spoke in support of the bill and voted in favor of its underlying principles at each stage of the parliamentary process. While it can be argued that the Church of England, through its episcopal representatives in the Lords, played a crucial role in the campaign for homosexual law reform, it must also be acknowledged that archbishops did not have the authority to line up their bishops to speak with one voice

\footnotetext{
${ }^{9}$ Ramsey's appointment as archbishop of Canterbury in 1961 represented an important shift in leadership. While his predecessor, Geoffrey Fisher, had adopted an ambiguous and occasionally antagonistic approach toward homosexual law reform, Ramsey immediately supported the Wolfenden recommendations and hoped that the law would soon be made more just, rational, and Christian. See Owen Chadwick, Michael Ramsey: A Life (London, 1990), 145-49.
} 
on "an issue in public affairs on which the Church, as such, has not, and cannot have, an official line." Instead, the church encouraged its bishops and clergy to follow their consciences, after referring to the advice of their church leaders and other guiding sources. ${ }^{10}$ This makes the extent of episcopal support for reform all the more remarkable; nevertheless, it led to a plethora of Anglican voices on issues of homosexuality.

To overstate the existence and reach of progressive Christian views on divisive issues of sexual morality is to obscure the complications of institutional decision making and to ignore the diversity of Christian opinion, the difficulties of reaching a consensus or forming a "church policy" and the problems of representing "church opinion." " While the bishops displayed a remarkably united front in the Lords debates, their actions concealed considerable disagreement and unease surrounding issues of homosexuality within the church. Private correspondence reveals that some bishops who spoke in support of the sexual offences bill were reluctant to do so, many offered excuses for nonattendance, and some refused outright to take part in the parliamentary debates. Lambeth Palace received so many hostile letters on account of the bishops' support for the sexual offences bill that it composed a standard letter of response. ${ }^{12}$ Nevertheless, despite considerable episcopal disagreement, only one bishop marked his unwillingness to reform the law by an abstention during one of the final parliamentary debates. ${ }^{13}$ Even though episcopal support for law reform was full of contradictions and remained a fairly limited exercise in terms of radically changing Anglican attitudes toward homosexuality, this striking appearance of general agreement among the bishops was, perhaps understandably, interpreted as marking a significant change in church policy. ${ }^{14}$

Religious support for homosexual law reform was not a marginal element in the debate, but made a significant difference to politicians and parliamentary legislators. In spite of the successes of Lord Arran's sexual offences bill when it was first introduced in 1965, homosexual law reform proved to be a fiercely controversial issue. The House of Commons did not vote in favor of reform until February 1966, and the government did not abandon its policy of neutrality until the summer of 1966, when opinion polls and voting in the House of Commons started to record more decisively in favor of reform. ${ }^{15}$ During this time, the bishops continued to

${ }^{10}$ See Geoffrey Fisher to H. A. Williams, 23 October 1957, Fisher 194, fols. 168-69, Lambeth Palace Library (hereafter LPL); Michael Ramsey to A. Hallidie Smith, 10 February 1959, Fisher 221, fols. 342-43, LPL; Fisher to Ramsey, 14 February 1959, Fisher 221, fol. 344, LPL.

${ }^{11}$ Laura Monica Ramsay, "The Ambiguities of Christian Sexual Discourse in Post-War Britain: The British Council of Churches and Its Early Moral Welfare Work," Journal of Religious History 40, no. 1 (March 2016): 82-103.

12 Ramsey 78, fols. 25-225, LPL; Ramsey 98, fols. 202-91, LPL.

${ }^{13}$ Ronald Williams (Bishop of Leicester): Parliamentary Debates, "Sexual Offences (No.2) Bill," Lords, vol. 284 (13 July 1967), cols. 1306-8. Williams, a Liberal Evangelical, became known for his opposition toward change: "Obituary-Rt. Rev. Ronald Williams," Times, 19 November 1979, 8. On the issue of homosexuality, Williams believed that the law should uphold Christian morality.

${ }^{14}$ For newspaper reporting of "church" support for homosexual law reform, see "Wolfenden Proposal May Win Peers' Support," Daily Mail, 20 April 1965, 5; “Time to Change a Bad Law," Guardian, 11 May 1965, 10; "Vice Bill Bid to Protect Mentally Ill," Daily Mirror, 4 June 1965, 3; "500 Sign Homosexuals Petition," Daily Mail, 8 February 1966, 7; "Bishops and Dons Petition Premier on Homosexuality" Guardian, 8 February 1966, 5.

15 Stephen Jeffery-Poulter, Peers, Queers, and Commons: The Struggle for Gay Law Reform from 1950 to the Present (London, 1991), 73-74, 77-81. 
support Lord Arran's bill as it repeatedly failed to pass through Parliament, and they joined in appeals to the government to find extra time and to sponsor and facilitate the bill's passage into law.

Lord Arran was convinced of the need for episcopal support for his bill. Throughout its long and difficult passage through Parliament, he was in close contact with Lambeth Palace, Michael Ramsey, and Robert Beloe. ${ }^{16}$ Arran kept an eager eye on which bishops were sympathetic and which unsympathetic toward his cause and was especially keen to secure the bishops' cooperation on any amendments to his bill. In his view, "The House could not fail to be impressed, and I think the Bill would have a better chance of getting through, if it were felt that the Lords spiritual were actively behind it." 17 Ramsey reciprocated this sentiment by ensuring that at each stage of the parliamentary debates there was enough episcopal representation to confirm the belief that "the angels are on Arran's side."18

A close reading of the parliamentary debates on the sexual offences bill confirms Arran's view that religious support for law reform was of considerable importance to politicians and parliamentary legislators. Throughout parliamentary proceedings, supporters of reform frequently referred to the views of the Christian churches, especially the opinions of the Established Church. Religious bodies were regarded as significant authorities on issues of sexual morality and an important source of informed opinion on homosexuality. It was therefore considered critical that, on the whole, religious leaders were seen to support reform. ${ }^{19}$ In the context of a wider, ongoing, public debate on the contested relationship between the law and morality-famously expressed by the academic dispute between legal philosophers H. L. A. Hart and Lord Patrick Devlin in the late 1950s and early 1960s-Christian leaders maintained a privileged position in ongoing disputes over how far the balance of moral decision-making should move from the public to the private sphere, and whether individual consent could take precedence over the imperatives of public morality. ${ }^{20}$ While some supported Devlin's argument that the law should protect and reinforce a shared morality based on those Christian principles that were generally upheld by society, others adopted Hart's view that it was no longer possible to determine such agreement on questions of morality; therefore this was no longer an acceptable basis for determining the laws of society. In supporting law reform, the bishops were seen to undermine one of the key arguments of the oppositionthe view that if the majority of a community disapproved of a particular conduct, such as homosexual acts, then it was right for that conduct to remain illegal. This,

${ }^{16}$ Ramsey 78, fols. 25-225, LPL; Ramsey 98, fols. 202-51, LPL; Ramsey 115, fols. 226-54, LPL; Lord Arran to Robert Beloe, 1 August 1967, Ramsey 3, fol. 268, LPL.

${ }_{17}$ Arran to Ramsey, 26 May 1965, Ramsey 78, fol. 71, LPL.

${ }^{18}$ Ramsey to Michael Gresford Jones (Bishop of St Albans), 9 May 1966, Ramsey 98, fols. 220-21, LPL.

19 See Parliamentary Debates, “Homosexual Offences,” Lords, vol. 266 (12 May 1965), cols. 79, 171; "Homosexual Reform," Commons, vol. 713 (26 May 1965), col. 612; "Sexual Offences Bill," Lords, vol. 269 (28 October 1965), col. 684; "Sexual Offences Bill,” Commons, vol. 724 (11 February 1966), cols. 791-93, 803-4, 846-47, 859, 866; "Sexual Offences (No.2)," Commons, vol. 731 (5 July 1966), col. 261.

${ }^{20}$ Patrick Devlin, The Enforcement of Morals (London, 1959), and H. L. A. Hart, Law, Liberty and Morality (Oxford, 1963). On the essence of the Hart-Devlin debate, see also Jeffrey Weeks, Sex, Politics and Society. The Regulation of Sexuality since 1800, 3rd ed. (Harlow, 2012), 325. 
in part, explains why supporters of the bill were so eager to underline episcopal support for reform. Lord Arran was keen to stress that his bill would reform the law without going beyond those essential moral principles that the bishops, as protectors of Christian morality, wished to uphold. He appealed to the bishops to table important amendments to his bill; he then pointed toward the integrity of these amendments, claiming that "for the Churches it must be a special concern that, in our desire for reform, we do not go too far and involuntarily undermine those moral standards which are permanent and absolute." 21

Parliamentary opponents also recognized the significance of episcopal support for the bill. Many speakers reacted strongly against the view that reform was generally endorsed by Christian churches, indicating that there was deep disunity within the Church of England between bishops, clergymen, and ordinary members, as well as within other Christian denominations, some of which disagreed altogether with the Wolfenden recommendations on homosexual offences. ${ }^{22}$ Reginald Manningham-Buller, first Viscount Dilhorne and leading opponent of reform in the House of Lords, expressed his grave concern that a change in the law would make it "very much more difficult to convince people that such conduct is wrong if now, with the backing of the leaders of the Established Church, it is made lawful." 23

It was precisely because homosexual law reform was such a divisive issue for political elites, the wider public, and the Christian churches that the bishops intervened by supporting Arran's sexual offences bill. The episcopacy viewed their support for the bill as a work of edifying the general public and steadily pushing opinion in favor of reform. ${ }^{24}$ The bishops were keenly aware of the intensity of controversy over issues of homosexuality and saw their role in terms of mediating in the dispute, and leading political elites and the wider public toward a responsible legal solution that could be supported by reformers and conservatives. Despite the outward appearance of episcopal consensus, it can hardly be said that the bishops were united in their attitudes towards homosexuality. While some took a more progressive stance, others were hostile towards homosexuality and reluctant reformers of the law. There was wide divergence, for example, between the views of Michael Gresford Jones, Bishop of St Albans, and Mervyn Stockwood, Bishop of Southwark, although both spoke in favor of law reform in the Lords debates. While Gresford Jones adopted an ambiguous and occasionally antagonistic role in the church's campaign for reform, Stockwood ardently pushed for change, motivated by his pastoral experience and his own celibate homosexuality. ${ }^{25}$ The episcopal consensus also included representatives of a

${ }^{21}$ Parliamentary Debates, "Sexual Offences Bill,” Lords, vol. 266 (24 May 1965), col. 633; Arran to Ramsey, 26 May 1965, Ramsey 78, fol. 71, LPL.

${ }^{22}$ See "Homosexual Offences," Lords (12 May 1965), col. 163; "Sexual Offences Bill," Lords (24 May 1965), cols. 688-89, 702-3; Parliamentary Debates, "Sexual Offences Bill," Lords, vol. 267 (21 June 1965), cols. 290-94, 309; "Sexual Offences Bill," Lords, vol. 268 (16 July 1965), cols. 411-12, 414; "Sexual Offences Bill," Lords (28 October 1965), cols. 708, 719-22; "Sexual Offences Bill," Commons (11 February 1966), cols. 797-99, 801-3, 846-47, 863-64; "Sexual Offences Bill," Lords, vol. 274 (10 May 1966), cols. 635-36; "Sexual Offences Bill," Lords, vol. 275 (16 June 1966), col. 166; “Sexual Offences (No.2) Bill,” Lords, (13 July 1967), cols. 1300, 1314, 1316.

23 "Sexual Offences Bill," Lords (21 June 1965), col. 293.

${ }^{24}$ Ramsey to Arran, 18 May 1965, Ramsey 78, fol. 47, LPL.

${ }^{25}$ Mervyn Stockwood, "Must I Bury Yet Another Man Because of This Hypocrisy and Humbug?," Daily Mail, 11 February 1966, 8; Michael De-la-Noy, "Stockwood, (Arthur) Mervyn (1913-1995)," 
range of churchmanship. This diversity among the episcopacy reflected the broadness, more generally, of the positions from which supporters backed Arran's bill. The moral consensus was broad enough to include progressives and conservatives.

Internally, homosexual law reform had been a fiercely contentious issue for the church ever since representatives of its Moral Welfare Council-the church's central organization for the coordination of thought and action in relation to issues of sex, marriage, and the family-had come out in the mid-1950s in support of the decriminalization of private homosexual acts between consenting adults. ${ }^{26}$ Anglican support for reform played an important role in the wider public debate at this time. ${ }^{27} \mathrm{Nevertheless,} \mathrm{while}$ this support undoubtedly mattered, it concealed a considerable amount of church conflict on the issue that continued to bubble beneath the surface. The Church Assembly debate in November 1957 emphatically underlined deep divisions among representatives of the bishops, clergy, and laity. The assembly narrowly approved the Wolfenden recommendations relating to homosexuality by 155 votes to 138 . The scarce majority indicated profound disagreement and, with under 50 percent of members actually recording their votes (the full strength of the Church Assembly was over seven hundred members), it was clear that this was a highly sensitive and difficult subject, upon which many members of the assembly were unwilling or unable to decide. ${ }^{28}$

In putting forward a shared reformist position, supporting Arran's bill precisely because homosexuality was such a contentious issue, the bishops applied the same strategy as had been developing within the church's internal decision-making bodies in the years since 1957. The limits of the church's Moral Welfare Council's support for the campaign for homosexual law reform were shaped by strong opposition to the Wolfenden proposals and determined the role that the council and its successor organization, the Board for Social Responsibility, perceived for the church, and pursued on its behalf, in the public debate. In 1957, the Moral Welfare Council officially and publicly supported the Wolfenden committee's recommendations on homosexual offences and approved of its definition of the function and scope of the criminal law in relation to sexual behavior. ${ }^{29}$ Nevertheless, while supporting the Wolfenden report in principle and considering reform as an inevitable and desirable future prospect, the Moral Welfare Council adopted an approach of extreme caution. The council regarded an immediate change in the law as inexpedient on the grounds that the public were not yet ready, and that the social and moral issues raised by reasonable and responsible people had not been addressed satisfactorily. The council wrote to the home secretary in February 1958, urging the government "to resist pressure put upon it to frame hasty legislation, the effect of which might be to drive the problem underground, ignoring social realities as well as principles

Oxford Dictionary of National Biography (hereafter ODNB), http://www.oxforddnb.com/view/article/ 57972, accessed 15 November 2017; "Obituary-Right Rev. E. M. Gresford Jones," Times, 9 March $1982,14$.

${ }^{26}$ The Problem of Homosexuality: An Interim Report by a Group of Anglican Clergy and Doctors (London, 1954); Sexual Offenders and Social Punishment, ed. Derrick Sherwin Bailey (London, 1956).

${ }^{27}$ Jones, Sexual Politics, 162-82; McLeod, "Homosexual Law Reform"; Willett, "The Church of England"; Grimley, "Law, Morality and Secularisation."

28 "Church Assembly Discusses Wolfenden Report. Opinion Divided Over Homosexuality Proposals," Church Times, 22 November 1957.

${ }^{29}$ Church of England Moral Welfare Council, Comment on the Wolfenden Report (London, 1957), 1-2. 
which society may well be found determined to uphold." Rather, the council encouraged the government "to adopt a policy which will encourage the education of public opinion and foster informed discussion in order that the issues may be clarified and responsibility be accepted more widely by society." 30 After 1957, the Moral Welfare Council and Board for Social Responsibility pursued their own policies of public edification-a step these organizations regarded as crucial in the long campaign for reform. Personnel of both entities believed that the church had a duty to seek a position in the debate that worked toward reconciling conflicting views, both within the church and broader society.

It is within this context that the bishops' support for homosexual law reform took shape. By 1965, it was widely believed that there had been some further adjustment of "public opinion," with more people in positions of influence willing to see the law reformed along the lines of the Wolfenden proposals. Lambeth Palace (like the Moral Welfare Council and Board for Social Responsibility) had come to view some change in the law on homosexual offences as right and necessary, but the episcopacy remained acutely aware of continued opposition within their own ranks and among the wider population. In response, the bishops took advantage of their position as parliamentary legislators and respected speakers on questions of morality, seeing it as their public duty to find a "responsible" legal solution to the issues raised by the Wolfenden report. Acting in their privileged position as members of the Lords, the bishops devised a role for themselves in terms of overseeing law reform, and ensuring that the new law could be supported by a majority of Anglicans, political elites, and members of the public. Above all, they wanted reform to be moderate and responsible, and this was why they supported Lord Arran's bill. ${ }^{31}$ Crucially, Arran was prepared to go out of his way to gain the support of the bishops. The episcopacy therefore played an important role in shaping the bill's major concessions, such as the higher age of consent for homosexual acts (as compared to heterosexual acts), the strict definition of "in private," and increased penalties for acts committed with persons under the age of consent. ${ }^{32}$ These concessions were intended to pacify opponents of the bill and secure its passage into law. ${ }^{33}$ They marked not only the outward limitations of the 1967 Act but, more importantly, were a manifestation of the wider contradictions of permissiveness in 1960s Britain.

${ }^{30}$ Ena Steel to the Rt Hon. Richard Austen Butler, 11 February 1958, MWC/HOM/7, Church of England Record Centre (hereafter CERC).

${ }^{31}$ See correspondence between Lambeth Palace and the Board for Social Responsibility, especially unsigned letter to Donald Coggan (Archbishop of York), 28 April 1965, BSR/MWC/HOM/2, CERC; "Paper B-Reform of the Law on Homosexual Offences, Moral Welfare Council," February 1961, Ramsey 78, fols. 80-81, LPL; Beloe to Ronald Williams, 1 June 1965, Ramsey 78, fol. 113, LPL.

${ }^{32}$ For the bishops' interventions on these issues, see "Homosexual Offences," Lords (12 May 1965), cols. 122, 133; "Sexual Offences Bill,” Lords (24 May 1965), cols. 662-63; "Note on the Sexual Offences Bill," 31 May 1965, Ramsey 78, fols. 83-85, LPL; "Sexual Offences Bill,” Lords (21 June 1965), cols. 344 45, 361-33, 374-75, 418-19, 424-25; "Sexual Offences Bill," Lords (16 July 1965), cols. 41618, 429, 431, 437-38; Parliamentary Debates, "Sexual Offences Bill,” Lords, vol. 274 (23 May 1966), cols. 1181-82; "Note on Homosexual Offences," 23 September 1966, Ramsey 98, fol. 249, LPL.

${ }^{33}$ On opponents' support for retaining additional areas of moral supervision in the 1967 Act, see Harry Cocks, "Conspiracy to Corrupt Public Morals and the 'Unlawful' Status of Homosexuality in Britain after 1967," Social History 41, no. 3 (2016): 267-84, at 275-76. 


\section{THE CHURCH, HOMOSEXUAL LAW REFORM, AND NARRATIVES OF RELIGIOUS DECLINE}

The bishops' understanding of their role, and that of the Church of England, in the campaign for homosexual law reform, as well as the high esteem in which their interventions were held by politicians and parliamentary legislators, has wider consequences for existing narratives of secularization. Until recently, the theory of secularization has been generally accepted by historians of modern Britain. Secularization theorists suggest that, since the late eighteenth and early nineteenth centuries, industrialization, urbanization, modernization, and associated developments have caused major obstacles for religion, leading to its decline in the West. ${ }^{34}$ While acknowledging that this decline was an uneven process, secularization narratives tend to assume a limited role for religion in modern societies. Historians have since problematized the timing of such accounts, the role of the churches in this process, and the indicators by which religious decline should be measured, yet the phenomenon of British secularization remains an open question.

Recently, historians have turned their attention to the postwar years, especially the 1960s. Yet while there is general agreement that Britain at the beginning of the 1950s was markedly different to Britain in 1970, scholars are less clear on what had changed, the extent of the change, or why the developments occurred. ${ }^{35}$ For the Church of England, the 1960s and '70s marked an obvious period of change. It saw a clear drop in church attendance, suggesting shifts in how British people viewed religion and how they thought they should organize their lives and beliefs. These developments were reflected and reinforced by the British media, the more highbrow sections of which began to discuss religious decline and gave prominence to Christian commentaries on the supposedly "secular" society. By 1965, it seemed as though Britain really was secular. The BBC moved from a declaredly Christian stance to a more neutral position, and Parliament passed a number of legal reforms, seemingly pushing the British population in a less strictly Christian and more secular and permissive direction. ${ }^{36}$

Yet while these observations are widely recognized in historical accounts, the chronology of religious decline remains in dispute. S. J. D. Green has suggested that Britain ceased to be a Christian country by 1960, but others time "de-Christianization” as slightly later. ${ }^{37}$ Hugh McLeod and Callum Brown maintain that 1950s Britain was generally considered to be a Christian country. It was widely accepted that its laws and national institutions should be shaped accordingly and that the churches should have a say on any public issue with a religious or moral dimension.

\footnotetext{
${ }^{34}$ See Steve Bruce, God Is Dead: Secularization in the West (Oxford, 2002); Alan D. Gilbert, The Making of Post-Christian Britain: A History of the Secularization of Modern Society (New York, 1980).

${ }^{35}$ See Weeks, Sex, Politics and Society, 321-56; Collins, ed., Permissive Society and Its Enemies; Lesley A. Hall, Sex, Gender and Social Change in Britain since 1880 (Basingstoke and London, 2000), 167-84; Arthur Marwick, The Sixties: Cultural Revolution in Britain, France, Italy, and the United States, c.1958c.1974 (Oxford, 1999).

${ }^{36}$ Sam Brewitt-Taylor, "The Invention of a 'Secular Society'? Christianity and the Sudden Appearance of Secularization Discourses in the British National Media, 1961-4," Twentieth Century British History 24, no. 3 (September 2013): 327-50; McLeod, Religious Crisis, 188-256; Brown, Religion and Society, 224-77.

37 S. J. D. Green, The Passing of Protestant England: Secularisation and Social Change, c.1920-1960 (Cambridge, 2011), 32-34, 90, 280, 305, 310-11.
} 
The churches remained powerful institutions, and clergy of the larger Christian denominations generally enjoyed high status and considerable influence. ${ }^{38}$ While McLeod dates religious "crisis" and change in western countries to the "long 1960s” (c.1958-74), Brown contentiously suggests that in Britain 1963 marked the crucial turning point. ${ }^{39}$

Part of the issue is that historians are divided over how best to measure religious change. Many use figures for church membership and attendance, as well as personal accounts. Increasingly in recent times, historians have seen attitudes towards sexual morality as a key indicator of religious decline, with permissiveness and its associated developments being viewed as an inherent part of the secularizing process. The legal reforms of the 1960s in particular are regarded as a revolutionary transformation that de-Christianized British law and society. ${ }^{40}$ Scholars disagree, however, over the churches' role in this transformation. For Callum Brown, the permissive legal reforms of the 1960s exemplified Christianity as a victim in the making; as the churches and religious ideas lost influence in government, education, and social welfare, Christian behavior became unenforceable by the state, and traditionally Christian-based laws on issues like homosexuality, abortion, divorce, suicide, and censorship had to be reformed. ${ }^{41}$ This account of the British churches' experiences - the idea that the majority of Christians focused their energy into resistance and repression and the churches quickly became casualties of a secularizing society-remains a popular view. ${ }^{42}$ Yet others have done much to complicate and contest this interpretation, refuting suggestions that British Christianity was passive in the face of inexorable cultural change from the 1960s onwards. These scholars convincingly demonstrate that the British churches contributed to permissive legal reforms and redefining sexual ethics, with the support of many important Christian groups and individuals. ${ }^{43}$ My own argument lends further support to that view. It also reveals more about when and how such changes took place, as well as why religious institutions like the Church of England acted in the ways they did.

The bishops' role in influencing the shape and passage of the 1967 Sexual Offences Act complicates the timing of secularization. Despite common assumptions that the Established Church was losing, or had lost, its influence in questions of sexual morality by the mid-1960s, key figures and organizations in the campaign for homosexual law reform continued to regard the church as a crucial player. As Hugh McLeod notes, religious arguments continued to play an important part in public debates, and their influence was at least equal to the secular and humanist case advanced in favor of reform. Legislators took "serious notice of the positions taken by the

${ }^{38}$ McLeod, Religious Crisis, 1-2, 39; Brown, Religion and Society, 180-81.

${ }^{39}$ McLeod, Religious Crisis, 1; Callum G. Brown, The Death of Christian Britain: Understanding Secularization, 1800-2000 (London, 2001), 1.

${ }^{40}$ McLeod, Religious Crisis, 215-28, 233-39; Brown, Religion and Society, 267-70.

${ }^{41}$ Brown, Religion and Society, xv-xvi, 1-8, 224-34, 236-49, 251-53, 267-70, 278-82, 290-91, 314-17, 319; Brown, Death of Christian Britain, 1-15, 170-80, 188-92, 193-98.

${ }^{42}$ See Dominic Sandbrook, White Heat: Britain in the Sixties (London, 2006), 457-67; Mark Donnelly, Sixties Britain: Culture, Society, and Politics (Harlow, 2005), 53-54.

${ }^{43}$ See Redefining Christian Britain: Post-1945 Perspectives, ed. Jane Garnett et al. (London, 2007), 29091; McLeod, Religious Crisis, 220-21, 231-39; Jane Lewis and Patrick Wallis, "Fault, Breakdown, and the Church of England's Involvement in the 1969 Divorce Reform," Twentieth Century British History 11, no. 3 (January 2000): 308-32. 
churches," particularly the Anglican Church, which occupied a "privileged position in the public debate" because of its status as the Established Church. ${ }^{44}$

Moreover, secularization was not something that happened to the churches with religious organizations having little control over that process. The role of prominent Anglicans and church decision-making bodies in the campaign for homosexual law reform refutes Brown's contention that, aside from a few slow-acting Christian liberals, the majority of churchmen responded to the "cultural revolution" (supposedly led by women and young people) by focusing "repressive, negative effort into their conception of religion as sexual restraint." 45 Not only were Anglican commentators ahead of Brown's "cultural revolution" in trying to rethink the basis of sexual morality in preceding decades but they played a crucial role in bringing about homosexual law reform at a time when there was limited support for such an idea. In this sense, the bishops' involvement in the campaign for homosexual law reform was an attempt to lead public opinion and to shape the wider consensus on which the moral landscape of the permissive society would be based.

The church's role in the campaign for homosexual law reform thus reinforces the idea of measuring the strength and influence of religion in alternative ways, beyond conventional indicators of institutional decline. 46 "Secularization" is a slippery and problematic concept that needs to be approached with sophistication. While falling levels of religious adherence and church practice were interpreted as indicators of decline, even "crisis," by contemporary observers (and later by sociologists and historians), this definition of secularization obscures a broader picture of religious persistence and transformation. ${ }^{47}$ In spite of undoubted changes that were taking place elsewhere in the life of religious institutions throughout the 1960s, leading church commentators, and the Church of England more generally, maintained a continued political and social authority in guiding approaches to issues of sexual morality.

As Matthew Grimley suggests, in the first half of the twentieth century the church retained a social significance out of proportion to its numerical strength through its role in creating and reinforcing a shared vision of values and mores, civic virtue, and mutual responsibilities, supported by Anglicans and non-Anglicans alike. Only in the 1960s and '70s did this moral consensus begin to break down and the idea of a national moral community begin to lose its resonance. ${ }^{48}$ In support of this view, the interventions of leading Anglicans in homosexual law reform indicates that the church preserved its position of authority on issues of sexual morality by appealing to British policy-makers, social commentators, professional individuals, and organizations in this way. Anglicans were thus able to play an important role in shaping the consensus in favor of reform, and providing significant support for that viewpoint from a religious and ethical perspective. If the church was still able to prominently intervene in national debates on issues of sexuality in the late 1960s, then it was in

${ }^{44}$ McLeod, Religious Crisis, 215-39.

${ }^{45}$ Brown, Religion and Society, 224-34, 236-49, 251-53, 267-70, 278-82, 290-91.

${ }^{46}$ For recent calls to reconsider how we measure religious strength and decline, see Garnet et al., eds., Redefining Christian Britain.

${ }^{47}$ Jeremy Morris, "The Strange Death of Christian Britain: Another Look at the Secularization Debate," Historical Journal 46, no. 4 (December 2003): 963-76, at 975-76.

${ }^{48}$ Matthew Grimley, Citizenship, Community, and the Church of England: Liberal Anglican Theories of the State Between the Wars (Oxford, 2004), 1-4, 11-13, 210-26. 
the 1970s that the moral climate began to shift. As the moral consensus on which homosexual law reform had been based began to crumble, the church lost its previous position of influence and authority.

\section{AGENTS OF PERMISSIVENESS?}

Anglican involvement in the campaign for homosexual law reform also has wider consequences for existing narratives of British permissiveness. The historiographical assumption that the permissive legal reforms followed on as a consequence of secularization needs to be challenged. ${ }^{49}$ Matthew Grimley contends that church leaders' advocacy of homosexual law reform in the 1950s and 1960s was principally about supporting a process of secularization of the law-something that church leaders believed was a necessary response to their misplaced perception that Britain had become a secular society. ${ }^{50}$ Yet, while Anglican support for reform was certainly informed by a growing impression among some commentators that Christian codes of sexual morality were coming under increasing attack and should no longer be unquestioningly enforced by the law, this was not the primary driving force behind the bishops' position, nor wider church support for decriminalization. Rather, that position was based on much longer traditions in redeveloping Anglican approaches towards questions of homosexuality, social policy, and the obligations of responsible sexual citizenship. Church support for homosexual law reform was not primarily a reaction to religious decline, whether real or imagined, but rather grew out of internal discussions within the church.

While recent work has concentrated on the sudden arrival and ascendancy of new Anglican discourses on homosexuality in the 1950s and '60s, the position in support of legal reform had a much longer historical genesis. The church had been revising its approach towards sexual morality since at least the 1920s. In Anglican discourse, responsible sexual citizenship was about giving rise to individual self-government in decisions surrounding personal sexual conduct. The idea was to encourage autonomy and freedom of choice in individual behavior, but Anglicans urged that all judgments must be made within the context of a Christian moral framework. According to this model of sexual citizenship, Christian sexual morality was becoming less about imposing an external code upon the life of the individual and more about encouraging individuals to make choices for themselves with the guidance of Christian principles. Most importantly, Christian advice pointed the way towards ensuring a careful balance between the two principles of pastoral care: sensitivity towards the needs and circumstances of the individual, and protection of the needs and well-being of the wider community or nation. ${ }^{51}$

Episcopal support for the sexual offences bill was based, first and foremost, on pastoral experience - most importantly, the bishops' belief that while homosexual behavior was morally wrong and should not be condoned or encouraged, the law was not an effective way of dealing with the offender, nor the most appropriate way of dealing with the "problem" of homosexuality. This episcopal position reflected earlier

\footnotetext{
${ }^{49}$ For recent support of this view, see Brewitt-Taylor, “The Invention of a 'Secular Society'?, 347-49.

${ }^{50}$ Grimley, "Law, Morality and Secularisation," 727, 739-40.

${ }^{51}$ Ramsay, "Christian Sexual Discourse," 100-1, 103.
} 
developments in Anglican thinking on questions of sexuality. It demonstrated the bishops' support for sympathetic and non-condemnatory approaches towards sexual sin, based on incorporating elements of sexological and psychological discourse into Christian sex teaching-an attitude that the church's moral welfare organizations had been looking to foster and develop since the interwar period. ${ }^{52}$ By the mid-1960s, such approaches were frequently adopted by Anglican proponents of homosexual law reform. The bishops in the House of Lords argued that homosexuals were not morally responsible for their "condition" and therefore deserved society's sympathy, help, and understanding rather than moral condemnation and threats of criminal punishment. ${ }^{53}$

Rooted in this primary concern for pastoral assistance, church support for homosexual law reform grew chiefly out of a desire to create conditions in which free choice could be exercised on a sound basis. This position was undoubtedly informed by a growing feeling among some Anglican commentators that Christian codes of sexual morality were coming under increasing attack, and that the church would lose support for its moral standards, particularly among the younger generation, if it did not get the emphasis of its teaching right. ${ }^{54}$ For Michael Ramsey, "the law, and the morality which it tries to uphold" needed to be "just," as well as "balanced, Christian and rational." He firmly believed that the "lopsided" version of morality being presented by the opponents of Lord Arran's bill was inconsistent with Jesus' teaching and was likely to be rejected by "people of the new generation." In his view, a change in the law was much more likely to win the "respect," "admiration," and "allegiance" of young people. ${ }^{55}$ Nevertheless, concerns over the secularization of society were not the starting point for Anglican positions of support for homosexual law reform. Rather, the crux of the bishops' argument rested on much longer developments in Anglican approaches towards issues of personal moral responsibility and Christian freedom.

In the years before 1965, Anglicans had started to rethink Christian approaches towards sexual morality; however, these new ideas were unevenly applied to homosexual issues, as compared to heterosexual ones. As is well known, in 1930, the statements of the Lambeth Conference-the decennial assembly of bishops from across the Anglican Communion-reflected a noticeable shift in Anglican approaches towards the issue of contraception. While previous pronouncements on birth control had tended to approach Christian sex ethics as an area for dictation, rigid direction, and prohibition, the 1930 Lambeth Conference presented the issue as a

52 Ibid., 89-91.

${ }^{53}$ Donald Coggan, Lewis Charles-Edwards (Bishop of Worcester), and Mervyn Stockwood, "Homosexual Offences," Lords (12 May 1965), cols. 121-24, 132-35, 153-56; Roger Wilson (Bishop of Chichester) and Stockwood, "Sexual Offences Bill," Lords (24 May 1965), cols. 659-63, 692-95; Michael Gresford Jones, "Sexual Offences Bill," Lords, vol. 274 (10 May 1966), cols. 615-18; Robert Stopford (Bishop of London), "Sexual Offences (No.2) Bill," Lords (13 July 1967), cols. 1290-91.

54 The most famous advocates of this view were proponents of the "new morality": see Towards a Quaker View of Sex: An Essay by a Group of Friends, ed. Alastair Heron (London, 1963); John A.T. Robinson, Honest to God (London, 1963), 105-21; Douglas Rhymes, No New Morality: Christian Personal Values and Sexual Morality (London, 1964).

55 "Sexual Offences Bill," Lords (28 October 1965), cols. 714-17; unsigned letter to V.G., 24 June 1965, Ramsey 78, fols. 163-64, LPL. 
matter of personal decision and responsibility. ${ }^{56}$ In this reconceived view of Christian sex ethics, the church's role was to provide Christian instruction and sex education, but final decisions were to be left to individual consciences. Birth control was to be treated as an area for sexual self-governance. ${ }^{57}$ This new Anglican approach remained fiercely contested in the years after 1930, but was overwhelmingly embodied in the later statements of the 1958 Lambeth Conference. That conference shifted the question of contraception for the first time entirely into the realms of "responsible freedom." "Responsible parenthood" meant the conscientious choice of a married couple on the number and spacing of their children, taking into account "their resources, the society in which they live, and the problems they face." 58 Rather than a prescriptive method, the bishops advocated a circumstantial approach towards family planning that put the onus on married couples to make moral decisions for themselves within a broader framework of guidance on "responsible" Christian living. While these earlier shifts in Anglican sex teaching only applied to heterosexual concerns, from 1965, church views on homosexuality finally began to reflect wider developments in Anglican thinking that had been gaining pace since the interwar period.

Only by situating episcopal support for homosexual law reform within this longer chronology can the bishops' arguments be fully understood. The idea of personal moral responsibility was fundamental to their position. Their support for decriminalization was based on a shared belief that true morality could not be enforced by coercive measures-that "it is not the purpose of the law to safeguard private morality, nor to shield the mature citizen from temptation to do wrong." True morality in the sphere of personal behavior meant "freedom to choose between right and wrong in the context of personal responsibility." 59 'The crux of the bishops' argument here was that the path towards moral self-regulation was impeded by the present law on homosexual offences. The bishops steadfastly maintained that they were in no way "condoning" or "extending social approval to homosexual conduct"-homosexuals, they argued, could rightly be considered morally responsible for their sexual behavior; homosexual acts were "always wrong," "intrinsically sinful," and "utterly

${ }^{56}$ For earlier Anglican statements, see the Lambeth Conference 1908 in The Six Lambeth Conferences, 1867-1920, compiled under the direction of Randall Davidson (London, 1920): Encyclical Letter, 310-11, Resolution 41, at 327, Committee Report, "Report of the Committee Appointed to Consider and Report upon the Subject of Marriage Problems," 400-2; the Lambeth Conference 1920 in The Six Lambeth Conferences: Resolution 68, at 44, and Committee Report, "Problems of Marriage and Sexual Morality," 112.

57 The Lambeth Conference 1930: Encyclical Letter from the Bishops with Resolutions and Reports (London, 1930): Resolution 15, at 43-44, Committee Report, "The Life and Witness of the Christian Community: Marriage and Sex," 89-92.

${ }^{58}$ The Lambeth Conference 1958: The Encyclical Letter from the Bishops Together with the Resolutions and Reports (London, 1958): Encyclical Letter, 21-23, Resolution 115, 57, Committee Report, "The Family in Contemporary Society," 142-50.

${ }^{59}$ Michael Ramsey, "Homosexual Offences,” Lords (12 May 1965), cols. 80-84; Mervyn Stockwood, "Sexual Offences Bill," Lords (24 May 1965), cols. 692-95; Roger Wilson, "Sexual Offences Bill," Lords (21 June 1965), col. 307; Michael Gresford Jones, Parliamentary Debates, "Sexual Offences Bill,” Lords, vol. 267 (28 June 1965), cols. 683-85; Gresford Jones, "Sexual Offences Bill,” Lords (28 October 1965), col. 695, and Ramsey, cols. 714-17. 
abominable. $" 60$ Nevertheless, the bishops insisted that the existing law defeated its own ends by discouraging homosexuals from accessing "the help, guidance and reformation which they need and which we believe it to be our duty to make possible for them." To this extent, a change in the law would, so the bishops believed, result in a more constructive situation whereby homosexual men would be in a better position to seek the reinforcement and counsel of priests, psychologists, sociologists, and other professionals who could encourage them to move away from "wrong" uses of sex, and to make better and alternative uses of their sexual energies. For Mervyn Stockwood, homosexual law reform was about rethinking "what we can do to help them [homosexuals] to integrate their lives usefully into the life of society." 61 Only with a change in the law, the bishops suggested, would normal morality resume among homosexuals, allowing the "problem" of immoral homosexual behavior to eventually disappear, or at least diminish.

An awareness that the moral consensus on which decriminalization was based was guided and informed by religious institutions such as the Church of England allows for the further interrogation of the shape and limitations of permissiveness in the 1960s. Not only was the church more responsible for molding the moral outlook of permissive legal reforms than previously assumed, but the episcopal approach towards law reform allows us to further confront some of the historiographical assumptions about the 1967 Sexual Offences Act. Scholars have already demonstrated that homosexual law reform cannot be categorized as part of a straightforward trend towards permissiveness. Rather, the new legislation was contradictory: it moved a discreet, responsible, and heavily privatized version of homosexual selfhood within the boundaries of social acceptability and formal citizenship, at the same time excluding individuals who did not conform to this type, and tightening up control and increasing regulation of unlawful homosexual behavior. ${ }^{62}$ However, there remains a historiographical assumption that the Sexual Offences Act legitimized private and discreet homosexual behavior in all senses. But this was far from the intentions of parliamentary supporters of reform who, like most other commentators at this time, saw homosexuality as a "problem" of social pathology that needed to be solved. ${ }^{63}$ Parliamentary support for the sexual offences bill was thus based fundamentally on therapeutic models, and hopes that homosexuality would disappear, or at least decline, as a "problem," once it was out in the open and better disposed to forms of "treatment" (conceived of as wider than just

${ }^{60}$ Ramsey, "Homosexual Offences," Lords (12 May 1965), col. 80; Gresford Jones, "Sexual Offences Bill," Lords (28 June 1965), col. 684, "Sexual Offences Bill," Lords (21 June 1965), col. 301; Wilson, "Sexual Offences Bill," Lords (24 May 1965), cols. 660-61.

${ }^{61}$ Ramsey, "Homosexual Offences," Lords (12 May 1965), cols. 80-84, Coggan, cols. 121-24, Lewis Charles-Edwards, cols. 132-35, and Stockwood, cols. 153-56; Wilson, "Sexual Offences Bill," Lords (24 May 1965), cols. 659-63, and Stockwood, cols. 692-95; Gresford Jones, "Sexual Offences Bill," Lords (28 October 1965), col. 696, and Ramsey, cols. 714-17; Ramsey, "Sexual Offences Bill," Lords (16 June 1966), cols. 154-55; Robert Stopford, "Sexual Offences (No. 2) Bill," Lords (13 July 1967), cols. 1290-91.

${ }^{62}$ Mort, Capital Affairs, 3-5, 355; Houlbrook, Queer London, 241-63; Hall, "Reformism," 7-15.

${ }^{63}$ On postwar discourses of homosexuality, see Chris Waters, "Disorders of the Mind, Disorders of the Body Social: Peter Wildeblood and the Making of the Modern Homosexual," in Moments of Modernity, Reconstructing Britain, 1945-1964, ed. Becky Conekin, Frank Mort, and Chris Waters (London, 1999), $134-51$. 
medical or psychological help, and certainly not meaning "reorientation," which most British experts agreed was unlikely). This position was not merely a sop to conservative opinion but was fundamental to the case for homosexual law reform. The Wolfenden report of 1957 was clear that its view that the "realm of private morality and immorality" was "not the law's business" did not in any way "condone or encourage private immorality," but rather it emphasized the idea that individuals had a "personal and private responsibility" for determining their own actions. Moreover, in its section on "therapeutic measures," the Wolfenden report argued that "treatment" (including the help of clergymen, social workers, probation workers, and "adjusted" homosexuals) could help individuals towards better social adjustment, as well as "making the man more discreet or continent in his behavior."64 Such a view was also the genuine essence of the episcopal position on homosexual law reform and needs to be taken seriously. Like Wolfenden, supporters of the sexual offences bill were anxious not to push the limits of reforming enthusiasm too far too soon.

By interrogating church support for the sexual offences bill, we gain further insight into the contradictions of homosexual law reform and its awkward location as part of a package of seemingly straightforwardly permissive, or wholly progressive, pieces of legislation. If campaigners later claimed that they had made their arguments in these terms, then they misremembered what it was politically possible to argue before 1967. While in context the episcopal position can be seen as heading in a liberalizing direction, it was also forcefully couched in the rhetoric of moral control and regulation. Further, this contradictory position was not limited to religious interventions in the public debate; the bishops' view was also the majority view of parliamentary supporters, including Lord Arran and Leo Abse, and it was largely shared by homophile organizations such as the Homosexual Law Reform Society. This moment of homosexual law reform thus reveals the existence of a contradictory and uneasy moral consensus among supporters of legal change. The episcopal position in the House of Lords for the most part represents the farthest reach of that consensus and reflects what it was possible and acceptable for social reformers and parliamentary legislators to argue at that time. To this extent, "permissiveness" and its legislative changes were characterized by deep contradictions - the process licensed certain areas of personal liberty while simultaneously tightening up controls and moral regulation in other areas. ${ }^{65}$ In this sense, "permissiveness" and its related notions of self-government and the legalization of consent always took place within certain boundaries. Like the bishops, this process moved in conflicting directions and involved compromises between a selective privatization of morality and its restriction in other ways.

\section{THE CHURCH'S RELATIONSHIP WITH THE HOMOPHILE MOVEMENT}

The contradictions of permissiveness are further exposed by examining the church's relationship with the homophile movement between 1958 and 1970. While there was certainly tension surrounding their different approaches towards homosexual law reform, there was a great deal of common ground and some cooperation

${ }^{64}$ Report of the Committee on Homosexual Offences and Prostitution, 24, 66-67, 73-74.

${ }^{65}$ Hall, "Reformism," $1-43$. 
between the church and homophile campaigning groups in the years up until the passing of the Sexual Offences Act. This revelation confirms our understanding of homosexual law reform as a complicated and contradictory moment in the movement towards a permissive society. If campaigning groups with more dogged determination to see greater changes to the criminal law were able, and wanted, to find areas of agreement with church thinking, then it is apparent that there was a wide moral consensus on issues of homosexuality between 1958 and 1967, which quickly broke down after the passing of the Sexual Offences Act. ${ }^{66}$ This break in viewpoints was firmly established with the advent in 1970 of the gay liberation movement and its pursuit of a more radical political agenda. The association between the Established Church and campaigning organizations also complicates our existing narratives of secularization still further. It is difficult to ignore the fact that key figures and organizations in the campaign for homosexual law reform continued to operate under the assumption that the Established Church wielded significant authority.

One might easily assume that Christian institutions were hostile to homophile organizations like the Homosexual Law Reform Society, and vice versa. Certainly "religion" became a common target of successor campaigning organizations like Outrage! and the Gay Liberation Front. ${ }^{67}$ Likewise, religious groups and individuals such as Mary Whitehouse targeted the gay liberation movement in moral purity campaigns of the 1960s and '70s. ${ }^{68}$ Nevertheless, as recent work on the Scottish churches has suggested, the relationships between Christian institutions and homosexual rights organizations were sometimes closer and more cooperative than we might think. ${ }^{69}$ In the years between 1958 and 1967, the church maintained a cooperative, albeit uneasy, association with the Homosexual Law Reform Society and the Albany Trust. These reforming organizations, together with Anglican supporters of law reform, shared a common attitude towards homosexuality that allowed for a broad degree of common purpose.

The Homosexual Law Reform Society was a largely middle-class pressure group, formed in 1958 to campaign for the decriminalization of homosexual offences in Britain. In the same year, the society established a separate organization and registered charity, the Albany Trust, to complement its work and specifically consider the psychological and social issues relating to homosexuality. In the lead-up to the 1967 Sexual Offences Act, the Homosexual Law Reform Society used conventional behind-the-scenes lobbying tactics to pressure MPs for reform. Like many campaigners, the Homosexual Law Reform Society argued that most homosexuals were respectable members of society and did not deserve to be criminally penalized. As a pressure group, however, the society's influence was limited; it was not directly consulted on the wording of the sexual offences bill and was unable to stop parliamentary

${ }^{66}$ The Homosexual Law Reform Society wanted Arran's bill to specify a lower age of consent and to contain a less intrusive definition of "in private." See Antony Grey, Quest for Justice (London, 1992), 100-10.

${ }^{67}$ Matt Cook, "From Gay Reform to Gaydar, 1967-2006," in A Gay History of Britain: Love and Sex between Men since the Middle Ages, ed. Matt Cook (Oxford, 2007), 179-214, at 179, 207.

${ }^{68}$ Tim Newburn, Permission and Regulation: Law and Morals in Post-War Britain (London, 1992), 32-36.

${ }^{69}$ Meek, "Scottish Churches," 607-13. 
legislators from limiting the bill's scope. Compared to later gay liberation organizations, the society was a fairly moderate organization; it required no endorsement of homosexuality from its members, only a belief that the present law was unacceptable. Many of its members were heterosexual, and it hesitated over the appointment of "open" homosexuals to its executive committee. ${ }^{70}$

The Homosexual Law Reform Society regarded Christian organizations as powerful participants in the public debate. From the outset, the society sought to secure the support of the "most important Christian and secular bodies concerned with the problem [of homosexuality]."7l Founding trustees of the Homosexual Law Reform Society and Albany Trust included A. E. Dyson, a university lecturer who spent his life moving in and out of the Church of England, and Reverend Andrew Hallidie Smith, a young, married Anglican clergyman who gave up his curacy in Birmingham to become the first secretary of the Homosexual Law Reform Society and Albany Trust (1958-60). ${ }^{72}$ John and Venetia Newall, succeeding joint secretaries of the society and Albany Trust (1960-62), wrote to the Board for Social Responsibility in 1960 expressing their executive committee's belief that the church had a responsibility to provide a moral "lead" for other interested individuals and organizations: "The Church of England must remain moral arbiter" in the debate on homosexual law reform. ${ }^{73}$ Similarly, Antony Grey, a former journalist, secretary of the Homosexual Law Reform Society and Albany Trust (1962-70), and later director of the Albany Trust (1971-77), was convinced that "a protracted period of lobbying for broadly based religious, political and social work support" was essential to the organization's campaigning success. ${ }^{74}$ Even though church backing was rarely forthcoming, in the years between 1958 and the early 1970s the Homosexual Law Reform Society and Albany Trust remained consistently keen to create and maintain links with the Moral Welfare Council and Board for Social Responsibility, to coordinate activities, and to secure church support for campaigning projects, especially those aimed at improving the "social treatment" of homosexuality. The Homosexual Law Reform Society "particularly hoped to obtain the support of the Church ... as we are firmly convinced that the Church can play a vital part in bringing disorientated homosexuals back into the community." 75 To these ends, campaigners eagerly sought to gain the confidence of church personnel-members of moral welfare bodies, clergymen, bishops, and archbishops alike. ${ }^{76}$

${ }^{70}$ Julian Jackson, "Homosexuality, Permissiveness and Morality in France and Britain, 1954-1982," in Collins, ed., Permissive Society and Its Enemies, 80-96, at 80-81, 89-91.

${ }^{71}$ A. E. Dyson to Gresford Jones, 31 March 1958, BSR/MWC/HOM/1, CERC.

72 See Brian Cox, "Dyson, Anthony Edward (1928-2002)," ODNB, www.oxforddnb.com/view/article/ 77161, accessed 15 November 2017; Grey, Quest for Justice, 26-30, 34, 47.

${ }^{73}$ John Newall to Gordon Dunstan, 15 November 1960, BSR/MWC/HOM/1, CERC. See also Grey, Quest for Justice, 47-49, 53, 57-58.

${ }^{74}$ Grey, Quest for Justice, 154-55.

75 Dyson to Steel, 13 May 1958, BSR/MWC/HOM/1, CERC; Newall to Ramsey, 2 November 1961, Ramsey 8, fol. 132, LPL; Antony Grey, "How Should We Treat Homosexuals? The Church's Role, a Paper Submitted to the BSR Working Party on Homosexuality," 8 May 1968, Ramsey 133, fols. 274-77, LPL.

${ }^{76}$ See various correspondence in BSR/MWC/HOM/l, CERC, and the Archbishop Ramsey Papers, LPL. 
Throughout this period, the Homosexual Law Reform Society, Albany Trust, and Anglican supporters of law reform shared a common attitude towards homosexuality. All agreed that "homosexual behaviour must not be condoned or encouraged." The Homosexual Law Reform Society endorsed the views of Robert Mortimer, Bishop of Exeter, giving him a platform at a public meeting held in Westminster in 1960, at which he declared his support for law reform but maintained that "homosexual tendencies, if not controlled or eradicated, are destructive of human personality and of human society." All agreed that the practice of chastity was the only real solution to the homosexual's problems. ${ }^{77}$ The Homosexual Law Reform Society shared the view put forward by the archbishop of Canterbury "that only with a change in the law will 'the fresh air of normal morality begin to circulate far more easily' among homosexuals." 78

In this connection, the Homosexual Law Reform Society, Albany Trust, and Anglican supporters of law reform agreed that homosexuals needed psychological and pastoral care and treatment and that the church had a vital part to play in this regard. Between 1957 and 1966, the Moral Welfare Council, Albany Trust, and Homosexual Law Reform Society, along with other interested individuals and organizations, were involved in several unsuccessful attempts to set up a clinic specifically for the treatment of homosexuals. By "treatment," the projects mostly implied "adjustment" to living as a homosexual, although it was considered that psychological reorientation to a heterosexual disposition might be possible in a minority of cases. The clinic was mostly intended to act as an advice center, "worry clinic," and social center for homosexuals, but it was also intended to provide education for the general public and professionals coming into contact with homosexuals. ${ }^{79}$

With these significant areas of agreement, several prominent Anglicans felt able to endorse the Homosexual Law Reform Society and Albany Trust in a personal capacity. A few Anglican bishops, including Michael Ramsey in his earlier position as Archbishop of York, were willing to add their signatures to public petitions organized by the society. ${ }^{80}$ Additionally, several bishops and leading church personalities became members of the society's "honorary committee." ${ }^{81}$ Most notably, and perhaps controversially, John Robinson, Bishop of Woolwich, became a member of the society's executive committee in the early 1960s.

Nevertheless, the extent of church support for homosexual law reform was misunderstood by homophile organizations, like the Homosexual Law Reform Society, that believed that "the church" was heading in the same direction in its attitudes

\footnotetext{
77 "Part of a Report of a Meeting Held at Caxton Hall, Westminster," 12 May 1960, BSR/MWC/HOM/ 1, CERC; Newall to Dunstan, 15 November 1960, BSR/MWC/HOM/1, CERC.

${ }^{78}$ Copy of a Letter to the Editor of the Times from Executive Committee Members of the HLRS, 8 November 1960, BSR/MWC/HOM/1, CERC. (The Times did not publish the letter.)

${ }^{79}$ See Correspondence and Papers on the Establishment of a Clinic for Homosexuals, April-August 1957, MWC/HOM/6, CERC; Correspondence and Papers on the Establishment of a "Worry Clinic" and Advice Center for Homosexuals, January 1961-March 1962, BSR/MWC/HOM/1, CERC; Correspondence and Papers on Clinical and Treatment Facilities for Homosexuals, August 1965-January 1966, Ramsey 78, fols. 226-51, LPL; Grey, Quest for Justice, 64-67, 132.

80 "Homosexual Acts. Call to Reform," Times, 7 March 1958; "Homosexual Offenders. Present Law Widely Discredited," Times, 24 November 1958.

${ }^{81}$ Progress Report of the Homosexual Law Reform Society, second issue, April 1959, BSR/MWC/ $\mathrm{HOM} / 1, \mathrm{CERC}$.
} 
towards homosexuality. Personnel of Lambeth Palace and the Moral Welfare Council, on the other hand, supported Lord Arran's bill precisely because they knew that organizations like the Homosexual Law Reform Society would not let the matter of law reform drop. As far as staff at Lambeth Palace were concerned, pressure groups like the society were aiming at reform too far in advance of what political elites and the general public would be prepared to accept. Consequently, church bodies refused to provide the Homosexual Law Reform Society or Albany Trust with any backing that might be considered official support. The Moral Welfare Council remained anxious about publicly associating itself with an organization that it considered to be "less responsible" and "possibly dangerous" in its campaigning activities. In the opinion of council staff, the Homosexual Law Reform Society and Albany Trust were unpredictable organizations, pursuing questionable strategies. Their more "hardened and impetuous campaigners" were likely to "do more harm by their agitation" for change. They had not fully understood the underlying reasons why the government, many bishops, and much of the community opposed reform; they had underestimated the seriousness and strength of this resistance to change; and they risked alienating reasonable and responsible members of the opposition. ${ }^{82}$ The Moral Welfare Council thus preferred to maintain informal links and casual representation.

The uneasy relationship between the church and these campaigning groups occasionally flared up into confrontation. In the early 1960s, the Moral Welfare Council's approach towards homosexual law reform was one of extreme caution, not resolved support. The Homosexual Law Reform Society found this a difficult policy to understand. While the society looked to "evolve some common attitude," church personnel remained reluctant to commit to any closer association with the homophile movement. ${ }^{83}$ In spite of this, the society and the Albany Trust continued to seek the church's support and assistance in future campaigning projects, not only because they were able to find wide areas of agreement with Anglican commentators, but because they regarded the church as an essential ally.

\section{COLLAPSE OF THE MORAL CONSENSUS}

The broad moral consensus on which the Sexual Offences Act had been based soon began to crumble. Its contradictions, once exposed, led to its unravelling and stored up considerable future problems for the church. Prior to this point, the more progressive strands of Anglican thinking had generally been in line with and had sometimes led the more liberal trends in thinking on homosexuality, allowing for areas of common agreement among unlikely allies, including Anglicans and other religious commentators, campaigning organizations, social commentators, and political

${ }^{82}$ Gresford Jones to Steel, 1 April 1958, BSR/MWC/HOM/1, CERC; Memorandum on Dyson prepared by Steel and Dunstan following a meeting on 9 April 1958, BSR/MWC/HOM/1, CERC; unsigned letter to Gresford Jones, 10 April 1958, BSR/MWC/HOM/1, CERC; unsigned letter to Dyson, 8 May 1958, BSR/MWC/HOM/1, CERC; Gresford Jones to Steel, 27 May 1958, BSR/MWC/HOM/1, CERC; Gresford Jones to Dyson, 5 July 1958, BSR/MWC/HOM/1, CERC; Dunstan to Lord Denning, 17 February 1961, BSR/MWC/HOM/2, CERC; Beloe's handwritten notes on a letter to Ramsey from the HLRS, 2 November 1961, Ramsey 8, fol. 132, LPL.

${ }^{83}$ Newall to Dunstan, 15 November 1960; unsigned letter to Newall, 21 November 1960, BSR/ MWC/HOM/1, CERC; Newall to Dunstan, 29 November 1960, BSR/MWC/HOM/1, CERC. 
elites. After 1967, however, Anglicans soon lost pace with progressive opinion. Despite the best efforts of more radical Christian commentators, the church's attitude generally began to fall out of favor.

In the 1970s, gay self-perception began to change, and a new, defiant, and revolutionary mood in sexual politics emerged. The gay liberation movement represented a radical rupture in approaches towards homosexual identity, politics, and social action. The Gay Liberation Front, formed in 1970, pursued a more militant and visible politics than the earlier homophile movement. Critical and defiant of authority, the Gay Liberation Front included among its tactics symbolic protests, street theatre, radical drag, and public demonstrations called "zaps." The organization advocated the unapologetic pursuit of a distinctive gay lifestyle, not least by its communal living in some places, urging homosexuals to "come out" and to take pride in their sexual identities. ${ }^{84}$ Unsurprisingly, the church soon found itself in confrontation with a movement that operated outside of the moral consensus and forcefully rejected its modus operandi. The Gay Liberation Front repudiated the Christian churches, psychiatry, the law, and other institutions for perpetuating the oppression of homosexual people. It also criticized the earlier homophile movement for compromising with this oppression. It distanced itself from the Homosexual Law Reform Society and Albany Trust by claiming to represent "the first pro-gay campaign without bishops." 85 Of course, not all gay rights organizations pursued such radical agendas during this period, but the gay liberation movement prompted other groups and organizations to respond to their agenda and forms of activism. ${ }^{86}$ This development presented the church with what would ultimately become insurmountable difficulties.

Part of the issue for Anglican commentators was that the newer language of minority rights was less easily incorporated into traditional Christian sex teaching than earlier approaches towards homosexuality. As Chris Waters suggests, between 1945 and 1968 there was a shift in the representational strategies through which homosexuality was rendered intelligible in Britain. Experts began to move away from an earlier, narrower focus on the psychological anatomy of male homosexuals and increasingly began to explore their larger social world and the dynamics of their social group (although slippages between these two models remained commonplace). ${ }^{87}$ But by the 1970 s, with the arrival of the anti-psychiatry movement and gay liberation, earlier psychological approaches began to be rejected in favor of viewing homosexuality as a social phenomenon. For many (but not all) commentators,

\footnotetext{
${ }^{84}$ Cook, "From Gay Reform," 179-83, 186-87, 189; Rebecca Jennings, A Lesbian History of Britain: Love and Sex between Women since 1500 (Oxford, 2007), 169-74; Lucy Robinson, Gay Men and the Left in Post-War Britain: How the Personal Got Political (Manchester, 2007), 68-80; Lisa Power, No Bath but Plenty of Bubbles: An Oral History of the Gay Liberation Front, 1970-73 (London, 1995).

${ }^{85}$ Grey, Quest for Justice, 175-84.

${ }^{86}$ The Albany Trust remained active, although less prominent, in the 1970s. For the Campaign for Homosexual Equality, see Cook, "From Gay Reform," 183-84. For lesbian social organizations and political activism, see Jennings, A Lesbian History, 169-89. For the Gay Christian Movement, which was founded in 1976, see McLeod, Religious Crisis, 185-86.

${ }^{87}$ For contemporary sociological studies of homosexuality, see Gordon Westwood [Michael Schofield], A Minority: A Report on the Life of the Male Homosexual in Great Britain (London, 1960); Richard Hauser, The Homosexual Society (London, 1962); Michael Schofield, Sociological Aspects of Homosexuality: A Comparative Study of Three Types of Homosexuals (London, 1965).
} 
homosexuals were increasingly conceptualized as members of a distinct social group or "minority," enjoying a distinctive "way of life." 88 This shift in approaches became problematic for the church in the years after 1967. Before the Sexual Offences Act, Anglican commentators had generally held to the view that the law needed to change so that homosexuals could better access psychological and pastoral care and treatment. Many genuinely believed that psychological care could assist homosexuals towards better personal and social "adjustment." This approach was popular among Anglican commentators (and others), not least because it aligned with traditional moral positions regarding homosexual behavior as wrong and sinful. Sociological approaches towards homosexuality, however, were less easily incorporated into traditional Christian discourse. While other commentators increasingly moved towards this approach, Anglicans remained unwilling to wholly commit to newer ways of conceptualizing homosexuality.

In accordance with their pastoral experience, Anglican commentators found it difficult to imagine homosexuals as a homogenous social group. The psychological approach towards homosexuality may have been part of the political rhetoric of reform, but commentators at the Moral Welfare Council and Board for Social Responsibility had always held that homosexual offences were not only committed by "genuine" homosexuals. Sometimes queer behavior took the form of casual or temporary liaisons or male prostitution, and involved individuals who did not selfidentify as different, and perhaps usually preferred heterosexual encounters. ${ }^{89}$ As Matt Houlbrook's study of queer urban life suggests, the boundaries between male sexual "normality" and "difference" only began to solidify in the two decades after the Second World War. ${ }^{90}$ Yet, even after that point, there remained some fluidity in sexual practices and identities. People continued to engage in same-sex acts without self-identifying as gay, even while others began to claim the status of a gay "subculture." For this reason, unlike rights campaigners who largely directed themselves towards assisting a particular type of individual after 1967, the church remained unable to commit to one particular view of homosexuality. While rights campaigners focused on a solidly defined "minority" with particular social needs, Anglican commentators remained wedded to an older idea more suited to "queer" types of sociability.

The rise of conservative evangelical opposition to the moderate reforms of the 1950 s and '60s also posed considerable difficulties for the church during the 1970s. The 1967 National Evangelical Anglican Congress at Keele University marked a decisive shift in the attitude and outlook of the Anglican evangelical movement towards engaging more fully with contemporary issues of social concern. ${ }^{91}$ In particular, the shift involved an increasing interest in issues of sexual morality. In the early 1970s, the Nationwide Festival of Light, a largely evangelical movement that

${ }^{88}$ Chris Waters, “The Homosexual as a Social Being in Britain, 1945-1968," Journal of British Studies 51, no. 3 (July 2012): 685-710. See also Jennings, A Lesbian History, 149-50, 160-63.

${ }^{89}$ The Problem of Homosexuality, 7-8; Sexual Offenders, 27-30; Homosexuality: A Review of the Situation after the Passing of the Sexual Offences Act 1967 (London, 1970), 7-8; Homosexual Relationships: A Contribution to the Discussion (London, 1979), 13-14.

${ }^{90}$ Houlbrook, Queer London, 3-10.

${ }^{91}$ Andrew Atherstone, "The Keele Congress of 1967: A Paradigm Shift in Anglican Evangelical Attitudes," Journal of Anglican Studies 9, no. 2 (July 2011): 175-97. 
campaigned against permissiveness and signs of moral decay, claimed to speak on behalf of a "silent majority" of Britons who, although no longer active Christians, still believed that sexual morality should be based on Christian principles. ${ }^{92}$ Such appeals to the "silent majority" continued to resonate throughout the 1970s and were ultimately embodied in approaches towards morality and religion under Thatcherism. ${ }^{93}$ For the Church of England, this development caused significant problems. Its traditional way of approaching controversial sex questions had always been by means of compromise, gradual change, and a search for consensus. The rise in opposition towards further shifts in Anglican teaching effectively blocked the church's ability to continue to move on issues of homosexuality.

After 1967, a noticeable split in Anglican attitudes towards homosexuality began to emerge. This division was reflected in two further reports produced by Board for Social Responsibility working parties during the 1970s-Homosexuality: A Review of the Situation (1970) and Homosexual Relationships (1979), also known as the Gloucester report. While the former presented these two incompatible views side by side, without passing judgment, the latter represented the first time that a church decision-making body had unanimously favored moving away from the moral consensus towards a new Anglican view of homosexuality. The report, however, caused considerable controversy for the church; it was simultaneously condemned by conservatives and liberals.

Of the two Anglican views that emerged in the 1970s, the first held firmly to the moral consensus outlined by the bishops in the parliamentary debates on the sexual offences bill. It reflected continued support for once dominant psychological and therapeutic approaches towards homosexuality, but with some alteration to take account of minority rights discourse. These Anglicans believed that there was still a place for psychiatric treatment, counselling, and case work of a befriending and practical kind for "the minority of cases who wish to be cured of their homosexuality and to the majority who need assistance to make the best of themselves as they are"; however, the church should avoid "acting in any spirit of condemnation" and refrain from "gratuitous sympathy" or unwanted "offers of help or treatment." 94 In agreement with conservative Anglo-Catholic and evangelical discourses on homosexuality, these Anglicans upheld the authority of scripture and tradition. They distinguished between the morally neutral "condition" of homosexuality and the morally culpable "choice" to indulge in homosexual behavior, tending towards the idea that "full and complete" homosexuality was rare and that many individuals could be "helped to overcome or, at least, sublimate" their sexual desires. For Anglicans of this view, the church had a responsibility to uphold a hard line on traditional moral categories of sin and to "seek to prevent those liable to temptation being led into homosexual practices." Homosexual relationships were regarded as always wrong and sinful, with

\footnotetext{
${ }^{92}$ Amy C. Whipple, "Speaking for Whom? The 1971 Festival of Light and the Search for the 'Silent Majority," Contemporary British History, 24 no. 3 (2010): 319-39.

${ }^{93}$ Matthew Grimley, "Thatcherism, Morality and Religion," in Making Thatcher's Britain, ed. Ben Jackson and Robert Saunders (Cambridge and New York, 2012), 78-94.

${ }^{94}$ Homosexuality: A Review of the Situation, 15-17.
} 
chastity the only acceptable solution for persons of "an exclusively homosexual disposition." $" 95$

The second Anglican view reflected a wider loss of confidence in psychological theories of homosexuality among the experts. In the years after 1967, many Anglicans became increasingly skeptical of therapeutic approaches and began to doubt the expediency of the church's earlier commitment towards promoting psychological "treatment" facilities for the "reformation and recovery" of homosexuals. 96 This position was essentially a rejection of that on which the bishops' support for the Sexual Offences Act had rested. In response to the politics of gay liberation, and in accordance with emerging sociological approaches towards homosexuality, this second Anglican view increasingly saw homosexuals as "a firmly defined class" deserving of "full social acceptance" and assistance towards living "the fullest and happiest existence possible." ${ }^{\prime 97}$ While maintaining that homosexual relationships were always second best and could "never be as fully human" or as "satisfactory" as heterosexual relationships, these Anglicans favored pushing Christian morality towards a scale of moral culpability whereby "a reasonably stable relationship with one person," even including physical acts, might not be condemned on the basis that this was to "do the best they can' in their situation." 98 This second view-which mostly took shape within the church's moral welfare organizations-did not accept claims to full homosexual equality, nor did it repudiate the view that sex rightly belonged within marriage and that marriage was between one man and one woman. ${ }^{99}$ Nevertheless, by the late 1970s, some Anglicans had come around to the view that homosexual relationships should be treated as a matter of personal decision and responsibility. Twenty years previously, the 1958 Lambeth Conference had for the first time shifted the issue of contraception entirely into the realms of "responsible freedom.” At that time, under the existing laws on homosexual offences, the idea of applying such thinking to the issue of homosexual relationships had been unimaginable. This revised Anglican approach was first articulated in Homosexuality: $A$ Review of the Situation; however, the view was not approved by the Board for Social Responsibility working party, nor was the report published or widely distributed. ${ }^{100}$ But in 1979 this revised Anglican approach was unanimously accepted by a published Board for Social Responsibility working party report. The Gloucester report concluded:

${ }^{95}$ For this first Anglican view, see: Homosexuality: A Review of the Situation, 10-17; Ronald Williams to Ramsey, 30 January 1970, Ramsey 180, fols. 225-27, LPL; Homosexual Relationships, 22-25, 51-52, 7071, 92-93.

96 Pauline Claisse to Beloe, 24 July 1967, Ramsey 115, fols. 256-59, LPL.

${ }^{97}$ Ramsey 180, fols. 225-27, LPL.

98 For this second Anglican view, see: Homosexuality: A Review of the Situation, 13, 15-19; Ramsey 180, fols. 225-27, LPL; Homosexual Relationships, 10-12, 22-25, 51-53, 93.

${ }^{99}$ Homosexual Relationships, 52, 67.

${ }^{100}$ Homosexuality: A Review of the Situation, 10-20; Ramsey to Ronald Williams, 27 February 1970, Ramsey 180, fol. 231, LPL; Claisse to Hugh Whitworth, 15 July 1970, Ramsey 180, fol. 236, LPL. Both the chairman of the 1970 Board for Social Responsibility working party, Stretton Reeve (Bishop of Lichfield), and the chairman of the Board for Social Responsibility, Ronald Williams (Bishop of Leicester), subscribed to the first Anglican view and did not want the church to further adjust its approach toward homosexual relationships. Both bishops had previously dissented from the episcopal consensus in the House of Lords by expressing misgivings about homosexual law reform. 
To declare that homosexuals may not in any circumstances give physical expression to their erotic love is unduly to circumscribe the area of responsible choice, to lay on individuals a burden too heavy for some to bear, and, by restricting the options open to them, to hinder their search for an appropriate way of life. ${ }^{101}$

While the membership of both Board for Social Responsibility working parties in the 1970s reflected a desire to represent "expertise" rather than balanced churchmanship, the controversy surrounding the Gloucester report suggests a resurgence in conservative Anglo-Catholic and evangelical opposition to any further adjustment of church thinking on homosexuality. Members of the Board for Social Responsibility were deeply divided about the report; some supported its general approach and conclusions, others strongly dissented from them. Led by their chairman Graham Leonard, Bishop of Truro, an Anglo-Catholic who strongly believed that the church should not change its sex teaching to suit contemporary mores, the board published a statement of "critical observations" as an appendix to the original report. ${ }^{102}$ This statement challenged the report's rereading of biblical testimony and tradition, concluding that it did not provide decisive evidence that church teaching should change. ${ }^{103}$ Board for Social Responsibility critics of the report included David Holloway, future founding member of the conservative Anglican evangelical organization Reform. ${ }^{104}$ Fervent criticisms of the Gloucester report, articulated by the Nationwide Festival of Light, the Church Times, Mary Whitehouse, and commentators at the Vatican, all centered on its re-reading of Scripture and tradition. ${ }^{105}$ Subsequently, when the Gloucester report came before the General Synod in 1981, members refused to take a vote on it and the report was effectively shelved.

This split in Anglican attitudes towards homosexuality was broadly reflected among members of the laity, clergy, and episcopacy, and since church commentators believed that these internal divisions mirrored wider differences among the experts and broader society, the church reached an impasse. In accordance with its traditional way of approaching controversial questions of human sexuality, church commentators believed that they could best aid the situation by making no immediate attempts to reconcile such bitter divisions. Rather, the Board for Social Responsibility resolved to set "the two alternative views" on homosexuality "side by side for study." Staff at Lambeth Palace, including Michael Ramsey, concurred with this approach, believing that it was "only by keeping both views in tension that the Church can help the world in this matter." In doing so, church personnel sought to "avoid 'polarization' of attitudes" that they believed would act to the detriment of those individuals who

${ }^{101}$ Homosexual Relationships, 52.

${ }^{102}$ John S. Peart-Binns, "Leonard, Graham Douglas (1921-2010)," ODNB, www.oxforddnb.com/ view/article/102956, accessed 15 November 2017.

${ }^{103}$ Homosexual Relationships, i-iii, 85-94.

${ }^{104}$ Mark Vasey-Saunders, The Scandal of Evangelicals and Homosexuality. English Evangelical Texts, 19602010 (Farnham, 2015), 82-86. Holloway published a further exposition of the "traditional" Christian viewpoint in disagreement with the Board for Social Responsibility working party: Michael Green, David Holloway, and David Watson, The Church and Homosexuality. A Positive Answer to Current Questions (London, 1980).

105 "Against Bible and Tradition," Church Times, 19 October 1979, 20; "Questions of Discipline," Church Times, 26 October 1979, 8; "Vatican Criticism of Homosexuality Report," Church Times, 26 October 1979, 24. 
identified as "exclusively" homosexual. ${ }^{106}$ In this way, however, the church effectively began to marginalize itself. The church unwittingly argued itself out of its previously central position in debates on homosexuality, in large part because it could not see its way towards re-evaluating the long-standing views of a significant section of its membership. While other groups and organizations increasingly left behind the moral consensus on which the Sexual Offences Act had been based, the church remained reluctant to fully align itself with changing notions of gay self-perception, nor could it see its way towards abandoning the traditional view of homosexual behavior as universally wrong and sinful.

This position of compromise was not enough to appease those individuals and organizations in pursuit of further legal changes and radical readjustments of public opinion. While personnel at the Board for Social Responsibility and Lambeth Palace hesitated over open discussion of issues that it believed to be highly complex and charged with irrational emotions, this was not a decided enough approach for gay rights campaigners. It also caused some unease and frustration for those Anglicans in favor of a new Christian response towards issues of homosexuality. In the years after 1967, there was increasing feeling among some Anglicans that the church's indecision would stand as a bar to its pastoral work with homosexual men and women. These commentators feared that the church's presumed intransigence might jeopardize its role in an important sphere of its traditional moral welfare work, especially if other organizations were seen as becoming more tolerant and accepting of homosexuals, while the church made no definite moves in this direction. ${ }^{107}$ This is precisely why successive Board for Social Responsibility working parties sought to fully present the emerging difference in Anglican attitudes, to demonstrate that there was disagreement about whether all homosexual behavior was essentially sinful, or how accepting the church was able to be of homosexual relationships.

Unsurprisingly, after 1967, relationships between the church and campaigning organizations such as the Homosexual Law Reform Society and Albany Trust became increasingly strained, as attitudes within the gay movement moved further away from what the church was willing to support. The uneasy relationship that had persisted in the lead up to the Sexual Offences Act eventually became a severe parting of ways. The church, being so divided among itself and believing that society was equally divided over questions of homosexuality, would not wholeheartedly support campaigns for further changes in the criminal and civil law, nor would it promote any radical readjustment of public opinion. ${ }^{108}$ As far as church personnel were concerned, by the early 1970s the opinions of organizations like the Albany Trust had become too steadfast and extreme. Board for Social Responsibility commentators regarded the trust's views-its commitment to recognizing persons

106 Note for Ramsey by Whitworth, 19 Feb 1970, Ramsey 180, fols. 229-30, LPL; Ramsey 180, fol. 231, LPL.

107 "Notes on Work with Homosexuals," [c.1967], BSR/MWC/HOM/2, CERC; Working Party on Homosexuality: Note, 28 March 1969, BSR/WP/HOM68/1, CERC; Homosexuality: A Review of the Situation, 15; Ramsey 180, fol. 236, LPL.

108 The Gloucester report advocated reform of the 1967 Act's definition of privacy and age of consent, but this view was not supported by the Board for Social Responsibility and some members registered their dissent: Homosexual Relationships, 54-65, 93. 
wanting to live as homosexuals as an accepted minority group with a distinctive pattern of sexual life no less socially acceptable and personally wholesome than that of married heterosexual couples, its support for the formation of legally recognized "homosexual social clubs," and its desire for some form of ceremony to stabilize homosexual unions akin to a marriage ceremony-as "dangerous talk, dangerous propaganda." Such positions, the Board for Social Responsibility felt, did not sufficiently consider "the deeper long term social implications" and risked "prejudicing efforts at soundly based steady education towards rationality and tolerance." Recognizing the precarious status of homosexuality in the post-law reform era, the board determined that the church could not "be associated with projects to bless active homosexuality," especially while some homosexual acts, such as buggery, were "still illegal and immoral." "The The Board for Social Responsibility also considered that the Albany Trust put "an unwholesome emphasis on merely physical sex acts," which it did not think appropriate for heterosexual or homosexual persons. Moreover, the board did not think it right for the church to encourage social segregation. The board wanted the church to instead promote means whereby homosexuals could become "accepted member[s] of a mixed society." As far as the board was concerned, it was dangerous to leave the initiative for education and public discussion of homosexuality to "pressure groups led by people too deeply involved at a personal level to see the issues from the point of view of the well being of the community as a whole." The board believed that homosexual individuals could provide "background help," but the task of digesting information and making value judgments could "only be done by those who have no personal problems likely to cloud their views." 110

The gay movement in turn hit back against the church, condemning its 1979 Gloucester report. The Campaign for Homosexual Equality described the report as "patronizing," "misinformed," and lacking in "faith, hope and charity."111 The Gay Christian Movement found itself unable to commend a report that it found to be "woolly-minded and pusillanimous" and viewed its major conclusions as "unchristian." 112 By the late 1970s, the church had effectively painted itself into a corner. The 1967 Sexual Offences Act had represented the last gasp of the once dominant socialtherapeutic reading of homosexuality. While that approach had been seen once as impeccably progressive, it now came under increasing attack. The new law had made way for the growth of sociological and minority rights discourse, a new questioning of therapeutic interventions, and a period of contesting and pushing the boundaries of the public/private distinction inherent to the 1967 settlement. Supporters of the 1967 Act, including bishops and other Anglican commentators, had unintentionally stirred up vehement criticism of their position from both gay

\footnotetext{
109 Cocks, "Conspiracy to Corrupt."

${ }^{110}$ Claisse to Whitworth, 30 March 1971, Ramsey 203, fols. 104-7, LPL; Note for Ramsey by Whitworth, 31 March 1971, Ramsey 203, fol. 108, LPL; Edwin Barker to JRA, 30 August 1968, BSR/MWC/ HOM/2, CERC; Memorandum, 2 March 1970, BSR/MWC/HOM/2, CERC; Ronald Williams to Barker, 9 March 1970, BSR/MWC/HOM/2, CERC; Barker to Lewis Charles-Edwards, 10 March 1970, BSR/MWC/HOM/2, CERC.

${ }^{111}$ Campaign for Homosexual Equality, "News Release," 19 October 1979.

112 Gay Christian Movement, "Press Release," 19 October 1979. For further criticisms from gay campaigning organisations see "Vatican Criticism," Church Times.
} 
rights campaigners and conservative groups, thus leading to the irrevocable collapse of the moral consensus.

\section{CONCLUSION}

The moral and sexual landscape of postwar Britain was thus shaped in surprising ways and by forces that existing narratives of religious decline tend to obscure. Contrary to our assumptions about secularization, religious authorities remained of real social and political importance and, despite deep divisions, the Established Church played a significant role in shaping the moral consensus that allowed for homosexual law reform in England and Wales. For Anglicans, the impetus for that support did not follow as a consequence of secularization; rather, church commentators supported permissive legal reforms due to internal developments that had a much longer historical genesis. Understanding the role of religious institutions such as the Church of England in helping to create the moral landscape of the permissive society helps us to explore the contradictions of permissiveness, not only in terms of the unexpected ways in which reform was shaped and brought about but with regard to the constraints of that new moral settlement that decriminalized homosexual behavior within modest boundaries. By identifying church support for homosexual law reform as part of a wider moral consensus, we are able to appreciate the contradictions of that position that involved broad agreement among an uneasy alliance of British policy makers, social commentators, professional individuals and organizations, and campaigning groups.

Yet if the church anticipated later shifts in sexual culture by way of Anglican support for homosexual law reform, it unintentionally left itself out in the cold in the years after 1967, when British society's sense of ethical judgment on homosexuality began to change. While other organizations and individuals were able to move away from the uneasy moral consensus that had allowed for legal reform, the church did not abandon its contradictions and thus faced considerable problems in trying to further alter its traditional teaching. With the resurgence in conservative Anglican opposition, particularly within its Anglo-Catholic and evangelical wings, the church's traditional way of approaching controversial sex questions-its search for gradual reconciliation between conflicting views-meant that the Anglican leadership was not able to move decisively enough for rights campaigners, and the church soon became a target and focus of criticism. Moreover, as it became increasingly difficult for the church to reconcile internal and external divisions in approaches toward sex ethics, its established means of functioning as an agent of compromise and consensus became increasingly unintelligible to British society. The church's apparent inability to move in the face of changing attitudes and sexual behavior only served to further underline and expose the contradictions of Anglican positions based on the now-crumbling moral consensus.

For the Church of England, secularization did not represent a radical break but rather a long, complicated, drawn-out process. The collapse of the moral consensus in the years after 1967 constitutes a significant part of that transformation. If the 1960s marked a period in which the church was still able to function as a leading voice in creating the moral landscape of the permissive society, the 1970s marked a period in which the church gradually ceased to function in this role. While the 
1970s did not witness a sharp ending to the influence of Anglican approaches toward sexual morality-rather, older worldviews continued to hold weight in ongoing public debates-the polarization of attitudes towards homosexuality after 1967 meant that the church could satisfy neither conservatives nor liberals. Anglicans thus ended up "behind the times," as the position from which the church had previously claimed to intervene in national debates on sexuality gradually came to be eroded. Once the moral consensus began to crumble, the church's accepted way of approaching controversial sex questions meant that its institutional policy came to be viewed as at best indecisive and at worst as dragging its feet on issues of sexual morality. 